Eur. J. Clin. Chem. Clin. Biochem.

Vol. 32, 1994, pp. 549-557

(C) 1994 Walter de Gruyter \& Co. Berlin · New York

\title{
Critical Evaluation of Fully Automated Enzyme Immunoassays for Free Thyroxine and Thyrotropin
}

\author{
By M. Mattiazzo and Indra Ramasamy \\ Department of Biochemistry, Repatriation General Hospital, Daw Park, Australia
}

(Received January 18/April 28, 1994)

\begin{abstract}
Summary: The technical and diagnostic performance of fully automated immunoassays for free thyroxine and thyrotropin using streptavidin/biotin technology (Enzymun-Test ${ }^{\circledR}$ ) were examined. The between-assay precision for free thyroxine was $10.4 \%, 5.4 \%, 2.5 \%, 2.3 \%, 1.1 \%$ and $1.8 \%$ at $3.02,6.27,17.2,21.9,25.6,42.7 \mathrm{pmol} / \mathrm{l}$; and for thyrotropin was $14.2 \%, 4.7 \%, 2.9 \%, 2.8 \%, 3.2 \%, 4.5 \%$ at $0.12,0.46,1.03,2.05,4.8,12.7 \mathrm{mU} / \mathrm{l}$. The functional detection limit of the assay was $0.09 \mathrm{mU} / \mathrm{l}$. Results for the free thyroxine method correlated well with the IMx $(r=0.91)$ and the equilibrium dialysis $(r=0.95)$ assay. Results for the thyrotropin method correlated well with the Tandem ${ }^{\circledR}$-TSH $(r=0.99)$ and the IMx $(r=0.99)$ assays. The euthyroid reference range was $11-23 \mathrm{pmol} / 1$ and 0.5-3.9 $\mathrm{mU} / 1$ for free thyroxine and thyrotropin respectively. The free thyroxine assay was not influenced by changes in albumin or thyroxine binding globulin concentration but showed increases at oleic acid concentrations $>4 \mathrm{mmol} / \mathrm{l}$. Spuriously elevated free thyroxine concentration were found in 4 patients, due to assay interference by antibodies in the serum. In a follow up study of 46 patients with non-thyroidal illness, serial measurements showed fluctuating free thyroxine and thyrotropin concentrations with abnormal results occurring in $34 \%$. In a hospital setting, a wider range of free thyroxine $(10-28 \mathrm{pmol} / \mathrm{l})$ and thyrotropin $(0.22-5.9 \mathrm{mU} / \mathrm{l})$ concentration may be observed in patients who are clinically euthyroid. Abnormal thyroid function tests were however transient and follow up resolved most diagnostic problems.
\end{abstract}

\section{Introduction}

The clinical laboratory must, today, select its free thyroxine and thyrotropin assays from a multitude of isotopic and non-isotopic and manual or fully automated methods available $(1-5)$. The measurement of thyrotropin and free thyroxine, in serum, in the clinical laboratory is however, still problematic. Many free thyroxine techniques give abnormal vạlues for patients with major quantitative or qualitative changes in thyroxine binding to serum proteins, and in non-thyroidal illness, especially in an intensive care unit setting (6). Thyrotropin assays vary in their quoted analytical sensitivity, and in the use of different calibrators constructed from different non human-based serum matrices (7). Also at present the majority of commercially available second generation thyrotropin assays cannot reliably distinguish between mildly subnormal thyrotropin values seen in hospitalised patients and the low values found in thyrotoxic patients (8).
Recently, fully automated tests using streptavidin/biotin technology for free thyroxine and thyrotropin (Enzymun-Test $\left.{ }^{\circledR}\right)$ were introduced on the automated immunoassay analyser, ES300 (Boehringer Mannheim, Mannheim, Germany). In theory, conjugate assays for free thyroxine such as the Enzymun-Test ${ }^{\circledR}$ are attractive because they have better accuracy than most analogue methods, and automated methods have better precision than manual immunoextraction methods.

The aim of this study was to evaluate the analytical and clinical performance of the Enzymun-Test ${ }^{\circledR} \mathrm{FT}_{4}$ and Enzymun-Test ${ }^{\circledR}$ TSH in a routine laboratory setting.

\section{Materials and Methods}

Samples

To determine the reference intervals for thyrotropin and free thyroxine, the serum concentrations were measured in 100 healthy euthyroid individuals (age $45 \pm 11$ years, 58 male, 42 female). 
Similarly free thyroxine and thyrotropin in the first and third trimester of pregnancy, oestrogen containing oral contraceptive and hormone replacement therapy wcre determined in apparently healthy cuthyroid subjects.

For method comparison studies, patient sera sent for routine thyroid function tests were used, and included hypo, hyper and euthyroid patients as well as those on thyroxine and the antiarrhythmic drug amiodarone.

The serum free thyroxine and thyrotropin were followed in two groups of patients with non-thyroidal illness. Group (1), 40 patients (age $74 \pm 9$ years, 30 male, 10 female) admitted to a general medical ward, with a variety of illness ranging from hairy cell leukaemia, cholecystitis, carcinoma of prostate, vertebral fractures, congestive cardiac failure, were followed over a period of 1 to 3 months. Following a retrospective study of the patients' medical records 5 patients with previous history of thyroid disease, 3 patients on steroid therapy and 4 patients on amiodarone were excluded from the study.

Group (2), 21 patients (age $74 \pm 5$ years, 20 male, 1 female) admitted consecutively to an intensive care unit were followed over a period of 1 to 5 weeks. The clinical conditions of the patients varied from bypass graft surgery, severe dehydration, partial gastrectomy, thrombectomy and aneurysm repair. Following patient review, 2 patients with prior record of thyroid disease and 1 patient on amiodarone were excluded from the study.

\section{Method}

\section{Thyrotropin}

The Enzymun-Test ${ }^{\circledR}$ thyrotropin assay is a two site immunoenzymometric assay involving a biotin labelled antibody and a second monoclonal antibody directed against a different antigenic site, labelled with horseradish peroxidase. Separation was by means of streptavidin coated tubes. The assay was performed according to manufacturer's specification, on the ES300. Seventy $\mu$ l of serum were incubated for 60 minutes at $25^{\circ} \mathrm{C}$, with $700 \mu \mathrm{l}$ of thyrotropin biotinylated antibodies $(1.5 \mathrm{mg} / \mathrm{l})$ and antibody conjugate in 80 $\mathrm{mmol} / \mathrm{l}$ phosphate buffer $\mathrm{pH}$ 7.4. The streptavidin coated tubes were aspirated and washed and the substrate diammonium 2,2azino-bis(3-ethylbenzothiazine-6-sulphonate) added. The colour intensity developed in thirty minutes was read at $422 \mathrm{~nm}$.

The standard concentrations, made up in 'protein matrix', approximated to $0.03,0.3,1.02,9.55,40.2 \mathrm{mU} / \mathrm{l}$.

\section{Free thyroxine}

The Enzymun-Test ${ }^{\circledR} \mathrm{FT}_{4}$ assay was carried out according to kit inserts, on the ES300. Twenty $\mu$ l of sample or serum was incubated for 30 minutes at $25^{\circ} \mathrm{C}$, with $500 \mu \mathrm{l}$ of biotinylated polyclonal sheep anti- $\mathrm{T}_{4}$ antibodies (antibody content $\geq 100 \mu \mathrm{g} / \mathrm{l}$ ) in 50 $\mathrm{mmol} / \mathrm{l}$ barbiturate buffer $\mathrm{pH} 8.2$. Thyroxine peroxidase conjugate $(500 \mu 1)$ was then added. After a further incubation for 30 minutes the streptavidin tubes with the reaction mixture were aspirated, washed and the substrate added. All patient sera were measured in singleton, for both assays.

\section{Sensitivity}

Analytical sensitivity, i. e. the minimum concentration at which results from a serum specimen can be considered statistically different from a zero calibrator $+2.7 \mathrm{SD}$ ( $99 \%$ confidence limit), the latter assayed 10 times, in singleton.

\section{Precision studies}

The between assay precision was calculated from the means of 10 singleton measurements of serum specimen aliquoted and stored at $-20^{\circ} \mathrm{C}$, and from three quality control sera with low, medium and high values. The assays were carried out over a period of days (thyrotropin) or weeks (free thyroxine).

The within assay precision was calculated from 10 singleton serum specimens.

\section{Linearity}

$: 1$

Linearity for thyrotropin was evaluated by two different parallelism studies. Serial dilutions were made of a sample with a high level of thyrotropin with serum containing undetectable levels of thyrotropin, or the thyrotropin diluent provided with the kit. A second sera with a value within the reference range was diluted with thyrotropin diluent to test linearity over the lower range of the assay.

\section{Method comparison}

The accuracy of the free thyroxine method was investigated by comparison with an equilibrium dialysis method (RLA analysis of the dialysate of the undiluted serum, Nichols Institute, San Juan Capistrano, Ca) and by the automated Abbott IMx System (Abbott Park, Il., thyroxine specific antibody on microparticles with microparticle enzyme immunoassay technology). The thyrotropin method was compared to the Abbott IMx system (Immunoenzymometric assay with microparticle technology, manufacturer's detection limit $0.03 \mathrm{mU} / \mathrm{l}$, reference range $0.32-5.0 \mathrm{mU} / \mathrm{l}$ ) and the Tandem ${ }^{\circledR}$-TSH (Hybritech, San Diego, Ca) high sensitivity assay (Automated immunoenzymometric assay using coated beads, manufacturer's detection limit $0.1 \mathrm{mU} / \mathrm{l}$, reference range $0.5-6.7 \mathrm{mU} / \mathrm{l}$ ).

\section{Other assays}

Serum thyroxine binding globulin and free triiodothyronine were measured by the Enzymun-Test ${ }^{\circledR}$ assays on the ES300. Prealbumin and human serum albumin were measured by rate nephelometry on the Beckman Array (Beckman Instruments, Ca.).

\section{Assay interference}

a. Non-esterified fatty acids - oleic acid in concentrations from 1-10 mmol/l was added to 'normal' serum from an apparently healthy individual and to patient sera with low and normal albumin levels (using the method of Mendel et al. (9)), i. e. an aliquot of a solution in isopropanol was evaporated under helium and the residue taken up at $37^{\circ} \mathrm{C}$ in serum solution.

b. Albumin - various concentrations of human serum albumin, fatty acid free (Sigma Chemical Company, St Louis) were added to patient sera with low albumin concentration. Negligible levels of free thyroxine were detected in solutions of human serum àlbumin $(40 \mathrm{~g} / \mathrm{l}$, $20 \mathrm{~g} / \mathrm{l}$ ) when measured by equilibrium dialysis and Enzymun-Test ${ }^{\circledR}$ $\mathrm{FT}_{4}$, suggesting that the albumin solution was essentially stripped of thyroxine. Patient samples were spiked such that minimal change in volume occurred (i. e. $180 \mu \mathrm{l}$ of concentrated albumin solution to $2 \mathrm{ml}$ ) and the albumin level in the patient sera measured by nephelometry. These samples were then assayed for free thyroxine by the Enzymun-Test ${ }^{\circledR}$ or equilibrium dialysis assay.

c. To determine the nature of proteins causing assay interference - Agarose linked goat anti-human polyvalent immunoglobulins or agarose linked goat anti-human IgG (Sigma Chemical Company), was mixed and centrifuged to remove excess liquid. Two hundred $\mu \mathrm{l}$ of serum were incubated with $200 \mu \mathrm{g}$ of the solid phase antibody. Free thyroxine assays were carried out on the preincubated serum.

\section{Statistics}

The curvefit method for the Enzymun-Test ${ }^{-F_{4}}$ and EnzymunTest ${ }^{\circledR}$ TSH was a Rodbard procedurè. Recalibration was a single point calibration on the third highessit standard (thyrotropin) or the 
second highest standard (free thyroxine). Linear regression analysis was used to test correlation between the different methods.

\section{Results}

\section{Sensitivity}

The analytical sensitivity was $0.08 \mathrm{mU} / 1$ for thyrotropin and $1.2 \mathrm{pmol} / \mathrm{l}$ for free thyroxine. For thyrotropin the functional sensitivity (between-assay CV 10\%) approximated to $0.19 \mathrm{mU} / \mathrm{l}$, or (between-assay CV 20\%) 0.09 $\mathrm{mU} / \mathrm{l}$. The analytical and functional sensitivity of the thyrotropin assay was similar to second generation thyrotropin assays previously studied (10).

\section{Precision}

Within- and between-assay precision are shown in figure la,b. The precision profile for thyrotropin showed the inverse relationship with low thyrotropin previously reported for other assays (10). The between-assay precision values for both assays, over the euthyroid range, fell within the calculated analytical goals based on intra-individual components of biological variation (11). Table 1 shows the inter-assay precision (CV) for the methods used for comparison.
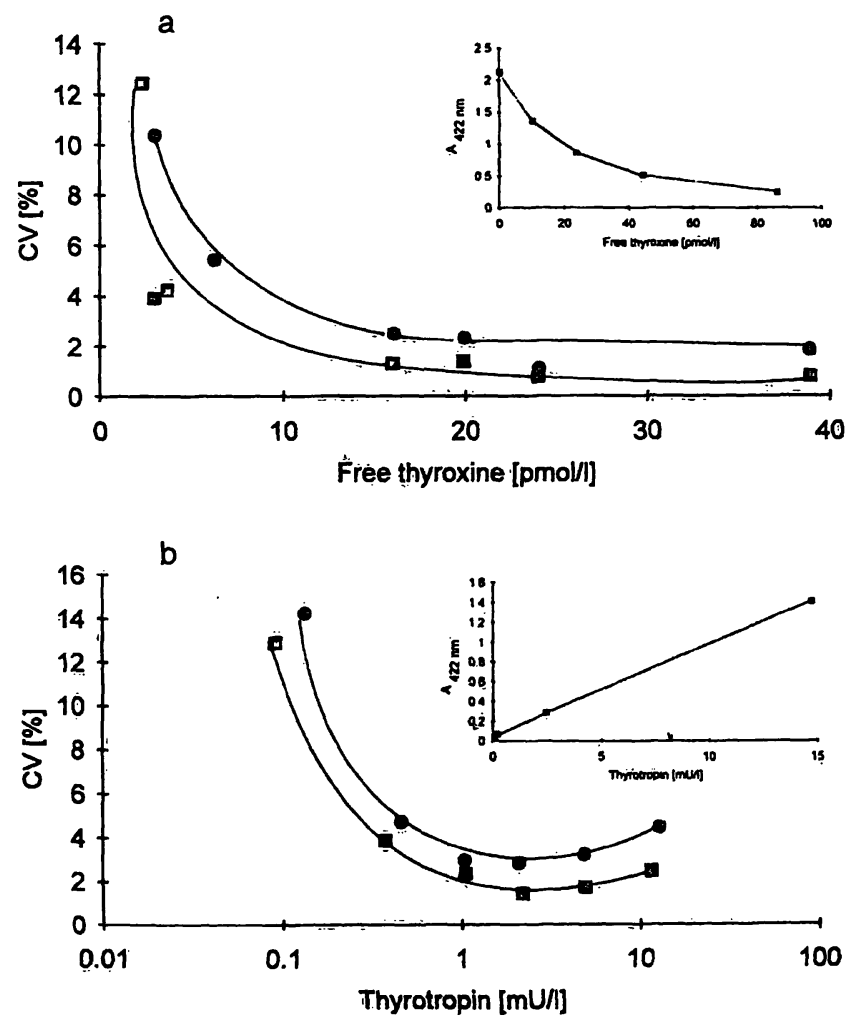

Fig. 1 Imprecision profile for (a) free thyroxine, Enzymun-Test ${ }^{(}$ $\mathrm{FT}_{4}$, (b) thyrotropin, Enzymun-Test ${ }^{2} \mathrm{TSH}$

within run precision

- between run precision

Insert shows the standard curve.

Tab. 1 Methods used for comparison - Inter-assay precision data*.

Method

Tandem ${ }^{\circledR}$-TSH $(\mathrm{mU} / \mathrm{l})$
mean
CV\%

Thyrotropin, IMx (mU/l)

mean

$\mathrm{CV} \%$

Free thyroxine, $\mathrm{IMx}(\mathrm{pmol} / \mathrm{l})$

mean

$\mathrm{CV} \%$

Free thyroxine, equilibrium dialysis

(pmol/l)

\begin{tabular}{lll} 
mean & 19.4 & 30.9 \\
CV\% & 10.9 & 14.0 \\
\hline
\end{tabular}

$* \mathrm{n}=10$

\section{Linearity}

Dilution experiments with thyrotropin diluent or a second serum showed linear dilution curves over the range 3.5-54 mU/1 and 0.1-3.4 mU/1.

\section{Comparison of methods}

\section{Analytical performance}

Figure 2a,b compares the Enzymun-Test ${ }^{\circledR} \mathrm{FT}_{4}$ assay with IMx free thyroxine, and free thyroxine $\left(\mathrm{FT}_{4}\right)$ by equilibrium dialysis. The assays correlated well with the following regression equations: $\mathrm{FT}_{4}(\mathrm{ES} 300)=3.0$ $+0.95 \mathrm{FT}_{4}(\mathrm{IMx})(\mathrm{r}=0.91, \mathrm{n}=98, \mathrm{Sy} / \mathrm{x}=4.0)$ and $\mathrm{FT}_{4}(\mathrm{ES} 300)=3.52+0.68 \mathrm{FT}_{4}$ (Equilibrium dialysis), $(r=0.95, n=61, \mathrm{Sy} / \mathrm{x}=3.2)$.

Figure $3 a, b$ compares the Enzymun-Test ${ }^{\circledR}$ TSH assay with thyrotropin by IMx and IMx and thyrotropin (TSH) by the Tandem ${ }^{\circledR}$-TSH assay. The assays correlated well with the following regression equations: TSH (ES300) $=0.008+1.17$ TSH (IMx) $(\mathrm{r}=0.99, \mathrm{n}=41, \mathrm{Sy} / \mathrm{x}$ $=0.39)$ and TSH $(\mathrm{ES} 300)=0.29+1.00 \mathrm{TSH}$ (Hybritech) $(r=0.99, n=97, \mathrm{Sy} / \mathrm{x}=0.5)$.

\section{Diagnostic performance}

Serum free thyroxine as measured by the EnzymunTest ${ }^{\circledR}$ and equilibrium dialysis methods concurred in the classification of 48 patients with free thyroxine values in the euthyroid range, 11 patients with free thyroxine in the hyperthyroid range and 2 patients with free thyroxine in the hypothyroid range. Free thyroxine by the ES300 and free thyroxine (IMx) agreed in the assessment 58 patients with free thyroxine in the euthyroid range, 27 patients with elevated free thyroxine concentration, and 10 patients with free thyroxine values below 

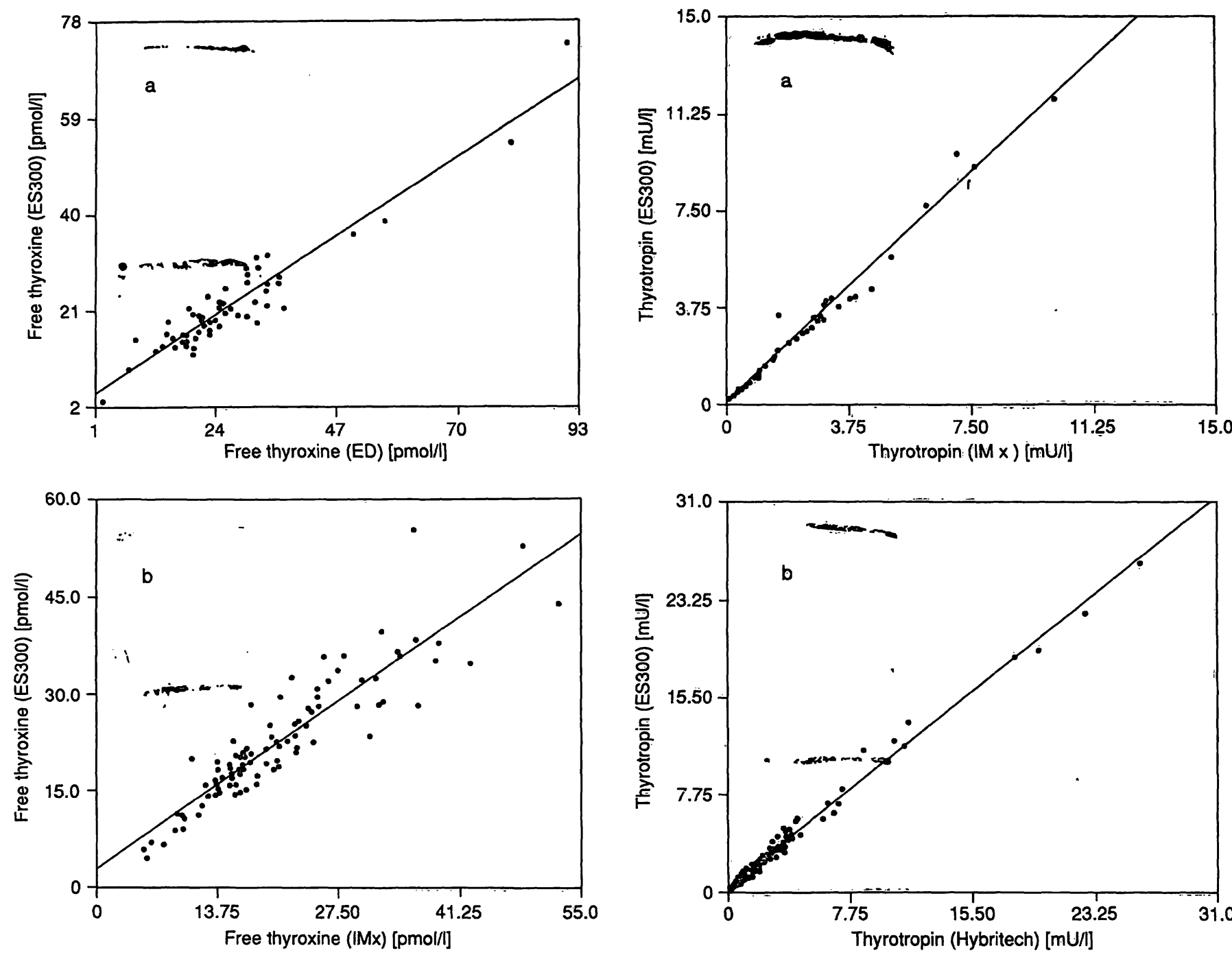

Fig. 2 Linear regression analysis between Enzymun-Test ${ }^{\circledR} \mathrm{FT}_{4}$ and free thyroxine by (a) equilibrium dialysis (ED), (b) IMx.

the reference range. However, 3 patients with free thyroxine values of $28.0,33.0,29.0 \mathrm{pmol} / 1$ by the Enzymun-Test ${ }^{\circledR}$ were classified as euthyroid by the IMx method. There were no clear reasons for these discordant values.

Serum thyrotropin as measured by the Enzymun-Test ${ }^{\circledR}$ and Hybritech correctly classified 69 patient sera with thyrotropin values within the reference range, 21 patient sera with thyrotropin above the reference range and 3 patients with suppressed thyrotropin. Four patients with thyrotropin levels within the reference range by the Hybritech method were classified as hypothyroid by the Enzymun-Test ${ }^{\circledR}$ method with thyrotropin values in the range 3.9-4.5 mU/1. Similarly thyrotropin by the Enzymun-Test ${ }^{\circledR}$ agreed with thyrotropin by IMx in the assessment of 28 patients with thyrotropin in the euthyroid range, 10 patients with elevated thyrotropin, and $3 \mathrm{pa}$ tients with suppressed thyrotropin.

A further 17 patients (not included in the regression analysis) were classified as having undetectable thyro-

Fig. 3 Linear regression analysis between Enzymun-Test TSH and thyrotropin by (a) IMx, (b) Hybritech Tandem ${ }^{\circledR}$ - TSH.

tropin by the IMx and Enzymun-Test ${ }^{\circledR}$ methods, but 9 patients with undetectable values by the IMx method had low but detectable values $(0.1-0.16 \mathrm{mU} / \mathrm{l})$ by the Enzymun-Test ${ }^{\circledR}$ method. Three patients with thyrotropin values below the detection limit by the Tandem ${ }^{\circledR}=\mathrm{TSH}$ assay had undetectable values by the Enzymun-Test ${ }^{\circledR}$ assay.

As the percentage of misclassifications were small $(<4.0 \%)$, the diagnostic performance of EnzymunTest ${ }^{\circledR}$ methods were considered to be equivalent to the comparison techniques; the characteristics of the latter have been described in previous studies $(12-15)$.

\section{Reference ranges}

The non-parametric reference intervals $(0.025$ and 0.975 fractiles) were $11-23 \mathrm{pmol} / 1$ for $\mathrm{FT}_{4}$ and $0.5-3.9 \mathrm{mU} / \mathrm{l}$ for thyrotropin (tab. 2). The free thyroxine mean value in the first trimester of pregnancy, $14.8 \mathrm{pmol} / \mathrm{l}$, was found to be significantly higher $(p<0.01)$ than the 
Tab. 2 Ranges of free thyroxine, thyrotropin and thyroxine binding proteins for an euthyroid population.

\begin{tabular}{|c|c|c|c|c|c|c|}
\hline & $\mathbf{n}$ & $\begin{array}{l}\text { Free } \\
\text { thyroxine } \\
(\mathrm{pmol} / \mathrm{l})\end{array}$ & $\begin{array}{l}\text { Thyrotropin } \\
(\mathrm{mU} / \mathrm{l})\end{array}$ & $\begin{array}{l}\text { Thyroxine } \\
\text { binding } \\
\text { globulin } \\
\text { (mg/l) }\end{array}$ & $\begin{array}{l}\text { Prealbumin } \\
(\mathrm{mg} / \mathrm{l})\end{array}$ & $\begin{array}{l}\text { Albumin } \\
(\mathrm{g} / \mathrm{l})\end{array}$ \\
\hline Euthyroid & 100 & $11-23$ & $0.5-3.9$ & $8-22 *$ & & \\
\hline 1st trimester pregnancy & 20 & $10-19$ & $0.4-3.2$ & $14-31$ & $150-290$ & $34-44$ \\
\hline 3rd trimester pregnancy & 20 & $9-14$ & $0.5-2.4$ & $17-36$ & $180-300$ & $26-39$ \\
\hline Hormonal contraception & 20 & $12-20$ & $0.6-3.4$ & $15-28$ & $240-450$ & $33-45$ \\
\hline Hornone replacement therapy & 20 & $12-20$ & $0.7-3.3$ & $14-29$ & $200-420$ & $33-44$ \\
\hline
\end{tabular}

$* \mathrm{n}=33$

mean value in the third trimester, $11.6 \mathrm{pmol} / \mathrm{l}$. The Enzymun-Test ${ }^{\circledR} \mathrm{FT}_{4}$ yielded normal results in hormone replacement and contraceptive pill therapy, despite increases in thyroxine binding globulin, suggesting that the conjugate does not bind to thyroxine binding globulin. Thyrotropin values for the latter groups fell within the reference ranges.

\section{Assay interference}

\section{a. Oleic acid}

Addition of oleic acid at values greater than $4 \mathrm{mmol} / \mathrm{l}$ increased the estimates of free thyroxine by both equilibrium dialysis and the Enzymun-Test ${ }^{\circledR}$ method in a serum sample from a 'normal' individual with an albumin value of $41 \mathrm{~g} / 1$ and prealbumin of $250 \mathrm{mg} / \mathrm{l}$. The increase in free thyroxine suggests that thyroxine is displaced from albumin and at higher concentrations from albumin and thyroxine binding globulin by non-esterified fatty acids (33). Patient sera with low values of albumin responded more sensitively than patient sera with albumin within the reference range (fig. 4). Endogenous free

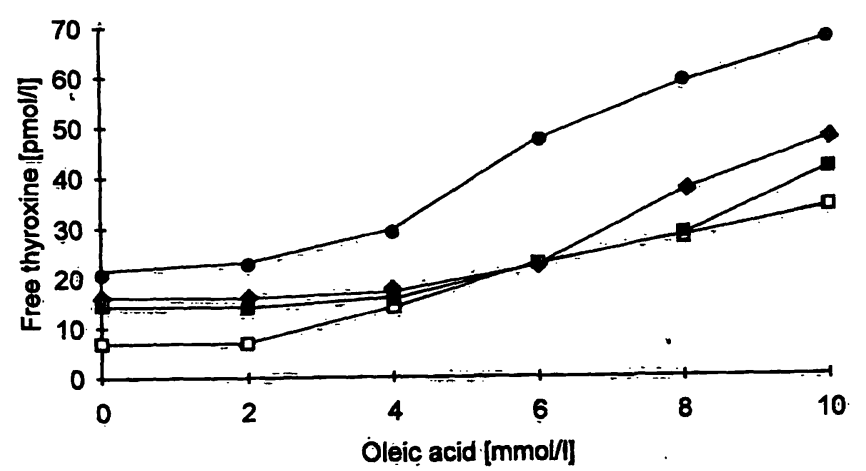

Fig. 4 Effect of oleic acid on free thyroxine measurements:

Free thyroxine by Enzymun-Test ${ }^{\circledR}$ 'normal sera', albumin $41 \mathrm{~g} / \mathrm{l}$, prealbumin $250 \mathrm{mg} / \mathrm{l}$.

¿ Free thyroxine by equilibrium dialysis 'normal sera', albumin $41 \mathrm{~g} / \mathrm{l}$, prealbumin $250 \mathrm{mg} / \mathrm{l}$.

- Free thyroxine by Enzymun-Test in patient sera with albumin $41 \mathrm{~g} / \mathrm{l}$, prealbumin $288 \mathrm{mg} / \mathrm{l}$, thyroxine binding globulin $11.9 \mathrm{mg} / \mathrm{l}$.

- Free thyroxine by Enzymun-Test ${ }^{3}$, in patient sera with albumin

$21 \mathrm{~g} / \mathrm{l}$, prealbumin $80 \mathrm{mg} / \mathrm{l}$, thyroxine binding globulin $15.6 \mathrm{mg} / \mathrm{l}$. fatty acids were not measured in patient sera but were assumed to be negligible in normal sera.

\section{b. Albumin}

Enzymun-Test ${ }^{\circledR} \mathrm{FT}_{4}$ values ranged from $16.4 \pm 0.21$ $\mathrm{pmol} / \mathrm{l}$ at $21 \mathrm{~g} / \mathrm{l}$ albumin, $16.2 \pm 0.15 \mathrm{pmol} / 1$ at $27 \mathrm{~g} / 1$ albumin, $16.0 \pm 0.22 \mathrm{pmol} / 1$ at $31 \mathrm{~g} / \mathrm{l}$ albumin, $16.2 \pm$ $0.24 \mathrm{pmol} / \mathrm{l}$ at $36 \mathrm{~g} / \mathrm{l}$ albumin and $15.9 \pm 0.15 \mathrm{pmol} / \mathrm{l}$ at $41 \mathrm{~g} / 1$ of albumin when a patient's sera was spiked with increasing concentrations of human serum albumin. For the same sera equilibrium dialysis free thyroxine values ranged from $26.3 \pm 1.37 \mathrm{pmol} / 1,24.8 \pm 2.0 \mathrm{pmol} / \mathrm{l}, 21.8$ $\pm 2.9 \mathrm{pmol} / \mathrm{l}, 21.8 \pm 2.7 \mathrm{pmol} / \mathrm{l}$ and $20.2 \pm 1.3 \mathrm{pmol} / \mathrm{l}$. An average of 6 determinations is given at each concentration.

The negligible effect of added albumin suggests that the horseradish peroxidase labelled thyroxine does not significantly bind to albumin. The slight decrease in free thyroxine values by equilibrium dialysis is explained by the long dialysis time (overnight) resulting in increased binding of thyroxine to serum albumin. As suggested from the regression line the results from the equilibrium dialysis method were generally higher than the Enzymun-Test ${ }^{\circledR} \mathrm{FT}_{4}$. These variations are reflected in the different reference ranges for both assays (Table 3).

\section{c. Antibody}

Four subjects, patients $A-D$, whose serum free thyroxine values by equilibrium dialysis and IMx were within the reference range, gave values above the reference range by the Enzymun-Test ${ }^{\circledR} \mathrm{FT}_{4}$ method (tab. 3). Thyrotropin, free triiodothyronine, thyroxine binding globulin, and prealbumin values were within the reference range. Preincubation of the patients' sera with agarose linked goat anti-human immunoglobulin, or agarose linked goat anti-human IgG decreased free thyroxine values by $52-71 \%$ compared to $7-20 \%$ in controls, suggesting that the cause of the spuriously elevated free thyroxine levels, were antibodies (type IgG) present in the sera. 
Tab. 3 Thyroid function tests: Immunoglobulin interference in the assay.

\begin{tabular}{|c|c|c|c|c|c|c|}
\hline \multirow[t]{2}{*}{ Patient } & \multicolumn{3}{|l|}{ Free thyroxine } & \multirow{2}{*}{$\begin{array}{l}\text { Free } \\
\text { triiodothyronine } \\
(\mathrm{pmol} / \mathrm{l})\end{array}$} & \multirow{2}{*}{$\begin{array}{l}\text { Thyrotropin } \\
(\mathrm{mU} / \mathrm{l})\end{array}$} & \multirow{2}{*}{$\begin{array}{l}\text { Recovery* } \\
(\%)\end{array}$} \\
\hline & $\begin{array}{l}\text { Enzymun-Test }^{\circledR} \\
(\mathrm{pmol} / \mathrm{l})\end{array}$ & $\begin{array}{l}\text { Equilibrium } \\
\text { dialysis } \\
\text { (pmol/l) }\end{array}$ & $\begin{array}{l}\text { IMx } \\
\text { (pmol/l) }\end{array}$ & & & \\
\hline $\begin{array}{l}\text { A } \\
\text { B } \\
\text { C } \\
\text { D }\end{array}$ & $\begin{array}{l}47.3 \\
39.5 \\
30.0 \\
29.6\end{array}$ & $\begin{array}{l}27 \\
23 \\
15 \\
18\end{array}$ & $\begin{array}{l}20 \\
19.4 \\
12.9 \\
17.4\end{array}$ & $\begin{array}{l}6.1 \\
4.9 \\
7.0 \\
5.7\end{array}$ & $\begin{array}{l}1.1 \\
2.8 \\
0.46 \\
3.7\end{array}$ & $\begin{array}{l}29 \\
41 \\
48 \\
41\end{array}$ \\
\hline $\begin{array}{l}\text { Controls } \\
(n=20)\end{array}$ & & & & & & $86.7 \pm 2.3$ \\
\hline $\begin{array}{l}\text { Reference } \\
\text { ranges }\end{array}$ & $11-23$ & $10-36$ & $9-24$ & $4.6-9.2$ & $0.5-3.9$ & \\
\hline
\end{tabular}

* Free thyroxine recovery after incubation of patient samples, and controls with agarose linked goat anti-human immunoglobulins.

\section{Clinical evaluation}

Group 1: Of the selected patients, 3 patients died during the study: 'Of these, a single patient with chronic renal failure had an abnormal thyrotropin concentration (5.6 $\mathrm{mU} / \mathrm{l})$. As in these patients, the focus of treatment was towards the underlying non-thyroidal illness, the abnormalities associated with thyroid function tests caused minimal interpretative problems.

In 8 of the remaining 25 patients, thyroid function tests showed transient abnormalities (tab. 4). One patient had consistently abnormal thyroid function tests over a follow up period of one month (free thyroxine $28.2 \mathrm{pmol} / 1$, thyrotropin $4.9 \mathrm{mU} / \mathrm{l})$. In this patient thyroid function tests became abnormal during repeated admissions for pulmonary oedema and furosemide therapy. As previously, her results were within the reference range (free thyroxine $15.1 \mathrm{pmol} / \mathrm{l}$, thyrotropin $2.8 \mathrm{mU} / \mathrm{l})$, her abnormal results were attributed to drug therapy. Overall in

Tab. 4 Transient abnormal thyroid function test results in patients with non-thyroidal illness.

\begin{tabular}{cll}
\hline Patient & $\begin{array}{l}\text { Free thyroxine } \\
(\mathrm{pmol} / \mathrm{l})\end{array}$ & $\begin{array}{l}\text { Thyrotropin } \\
(\mathrm{mU} / \mathrm{l})\end{array}$ \\
\hline Group 1 & & \\
1 & 26.3 & 1.0 \\
2 & 25.7 & 3.7 \\
3 & 27.0 & 1.9 \\
4 & 27.0 & 1.0 \\
5 & 20.9 & 4.2 \\
6 & 16.4 & 4.4 \\
7 & 20.8 & 4.7 \\
8 & 19.1 & 5.9 \\
& & \\
Group 2 & & 4.7 \\
1 & 17.5 & 5.9 \\
2 & 19.7 & 0.24 \\
3 & 15.8 & \\
\hline
\end{tabular}

hospitalised patients, classified as euthyroid, the free thyroxine values ranged from 11 to $28 \mathrm{pmol} / 1$ and thyrotropin values from 0.5 to $5.9 \mathrm{mU} / 1$.

Group 2: In the subgroup of selected patients, 5 patients died subsequently, and of these 3 patients had abnormal thyroid function tests at least one during follow üp (free thyroxine $11.3 \mathrm{pmol} / \mathrm{l}$, thyrotropin $0.22 \mathrm{mU} / \mathrm{l}$; free thyroxine $9.7 \mathrm{pmol} / \mathrm{l}$, thyrotropin $0.72 \mathrm{mU} / \mathrm{l}$; free thyroxine $21.3 \mathrm{pmol} / \mathrm{l}$, thyrotropin $4.4 \mathrm{mU} / \mathrm{l})$. A further 3 patients had transiently abnormal results (tab. 4). Two patients had consistently high but fluctuating thyrotropin levels (12.6 to $6.6 \mathrm{mU} / \mathrm{l}$ and 4.5 to $7.9 \mathrm{mU} / \mathrm{l}$ ) over a period of 4 weeks, suggestive of subclinical hypothyroidism.

In the remaining 8 patients a shift of free thyroxine values to higher concentrations was observed as the patient recovered. Free thyroxine and thyrotropin values fell within the reference ranges though there was considerable intraindividual variation during follow up (fig. $5 a, b)$. In patients in the intensive care unit, classified as euthyroid, free thyroxine ranged from $10-23 \mathrm{pmol} / \mathrm{h}$ and thyrotropin from 0.22 to $5.9 \mathrm{mU} / \mathrm{l}$.

\section{Discussion}

Several aspects of the thyrotropin and free thyroxine assays routinely in use in the laboratory were investigated during this evaluation. Precision, linearity and method comparison for the Enzymun-Test ${ }^{\circledR} \mathrm{TSH}$ and EnzymunTest ${ }^{\circledR} \mathrm{FT}_{4}$ were acceptable for clinical use. The functional assay sensitivity of $0.09 \mathrm{mU} / 1$ suggested that this was a second generation assay. Both assays were practicable and easy to use.

Long term low dose heparin therapy used in an intensive care setting can cause increases in plasma free fatty acid concentrations. Additions of, pleic acid, the most abun- 

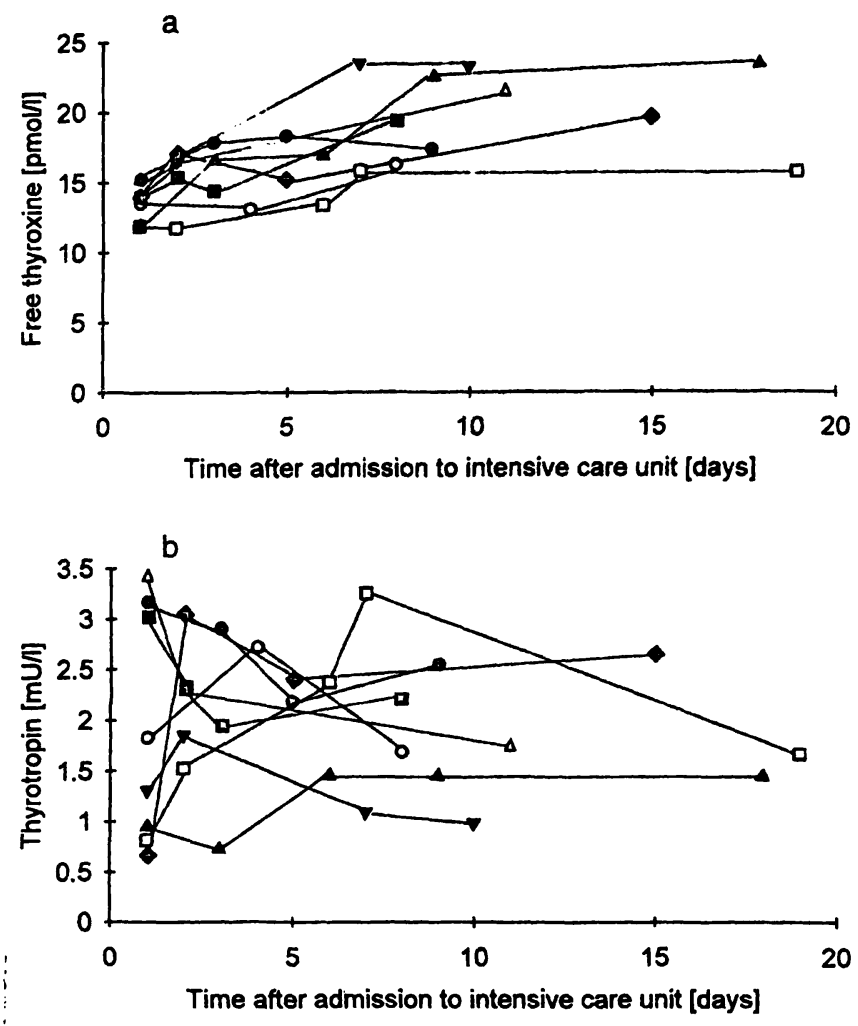

Fig. 5 Intraindividual variation after admission to the intensive care unit (a) free thyroxine (b) thyrotropin.

dant non-esterified fatty acid present in the serum (17), caused an increase in free thyroxine concentrations when levels reached approximately $>4 \mathrm{mmol} / \mathrm{l}$. Free thyroxine by equilibrium dialysis responded similarly. However, the clinical relevance of this observation is yet to be determined as the molar ratio of free fatty acids/ albumin that have a discernible effect on free thyroxine concentration is thought to vary from $2.5(19,20)$ to $>5.0(16,18)$.

Because dependence on carrier proteins might reduce the clinical usefulness of free thyroxine methods (21), we assessed the effect of albumin on the Enzyme-Test ${ }^{\circledR}$ $\mathrm{FT}_{4}$ assay.

Our results suggest that the current assay, like the equilibrium dialysis method is relatively free of albumin or thyroxine binding globulin dependence. This agrees with the manufacturer's claim that the horseradish peroxidase label is prevented from occupying serum thyroxine binding sites by steric hindrance.

Free thyroxine concentrations measured by the Enzymun-Test ${ }^{\circledR}$ assay decreases during the course of pregnancy, although individual results are only slightly below the reference range. As the technique yields results within the reference range in subjects with increases in thyroxine binding globulin as in hormone replacement or oestrogen therapy, at least part of the decrease can be assumed to be physiological (22); such individuals re- main euthyroid with thyrotropin levels within the reference range.

The study suggests that there is no perfect free thyroxine assay, as the theoretical premise of non-interference by antibodies in the assay is not fulfilled. This has been previously reported for other non-analogue assays (23, 24). The nature of the antibody, however, is yet to be determined. Anti-sheep antibodies affecting a radioimmunoassay for thyrotropin has been reported (25). These heterophilic antibodies can prevent the binding of the biotin labelled thyroxine antibodies to the streptavidin coated tubes, leading to spuriously high values. An isolated increase in free thyroxine should therefore be viewed with caution.

Non-thyroidal illness has been shown to affect thyroid function tests $(26-32)$. Thyroid function tests are therefore optimally performed in ambulatory and otherwise well patients, but there is a clinical need for determining the presence or absence of thyroid disease in patients with non-thyroidal illness. This is especially true in elderly patients $>50$ years, who suffer from chronic illnesses and benefit from treatment for thyroid dysfunction as well as in patients with myocardial infarction where the presence or absence of thyroid disease is to be established. The study shows that in such patients, normal, low or borderline high thyrotropin/free thyroxine values are possible. In most patients abnormalities in thyroid function tests were, however, transient. Furthermore, we noted that none of the patients had a subnormal thyrotropin and increased free thyroxine (suggestive of hyperthyroidism) or a high concentration of thyrotropin with a low free thyroxine (suggestive of hypothyroidism). Abnormal thyroid function tests associated with non-thyroidal illness, therefore caused few interpretative problems. Persistent increased or decreased thyrotropin concentrations during follow up may indicate subclinical hyper/hypothyroidism.

The average age in both groups of patients with nonthyroidal illness was 74 years. Although it has been reported that aging influences the outcome from thyroid function testing (12), there is evidence that 'normal' aging has little effect, i.e. when pharmacological and methodological effects are removed (34). The low prevalence of subnormal thyrotropin concentrations and the transient nature of the abnormalities, confirmed in previous studies with younger patients (27), suggest that the changes observed during non-thyroidal illness are not an age-related effect.

Doctor et al. (35) showed that in a large proportion of patients with non-thyroidal illness other non-analogue free thyroxine assays showed values above the reference 
range. Coupled with the observation of anomalous thyrotropin values in non-thyroidal illness, a strategy recommended in a hospital setting is the use of thyrotropin and free thyroxine assays on all patients with non-thyroidal illness $(36,37)$. The present study suggests that with the Enzymun-Test ${ }^{\circledR}$ technology diagnostic problems will arise infrequently with this approach. Further, automation of free thyroxine and thyrotropin will facilitate their concurrent measurement with minimal increase in manpower and laboratory time.

\section{References}

1. Mibler, U., Gaida, U. \& Wood, W. G. (1993) Development and evaluation of a time resolved immunofluorimetric assay for thyrotropin. Eur. J. Clin. Chem. Clin. Biochem. 31, 389393.

2. Tuuminen, T., Kapyaho, K. I., Rakkolainen, A. E. M., Bugrova, V. B., Tsukerman, G. L., Jesse, E. \& Sander, J. (1993) New neonatal thyrotropin enzyme immunoassay with fluorimetric detection: Comparison with time resolved fluoroimmunoassay. Eur. J. Clin. Chem. Clin. Biochem. 31, 49-53.

3. Bock, J. L. \& Wegge, J. (1992) Automated TSH assay: Comparison of the technicon immuno $1^{\mathrm{TM}}$ random-access analyser to three batch analysers. Abstract. Clin. Chem. 38, 1079.

4. Combs, B. S., Quick, L. M., Osikowicz, G. \& Brandt, D. (1992) Development of $T_{4}$ and $T_{3}$-uptake assays for the Abbott random/continuous access immunoassay analyser. Abstract. Clin. Chem. 38, 1089.

5. Yarnall, M. \& Link, W. (1992) A new highly sensitive TSH EIA for the Bio-Rad Radias system. Abstract. Clin. Chem. 38,1090

6. Kaptein, E. M., Grieb, D. A., Spencer, C. A., Wheeler, W. S. \& Nicoloff, J. T. (1981) Thyroxine metabolism in the low thyroxine state of critical nonthyroidal illnesses. J. Clin. Endocrinol. Metab. 53, 764-772.

7. Gaines-Das, R. E., Brettschneider, H. \& Bristow, A. F. (1991) The effects of common matrices for assay standards on performation of "ultrasensitive" immunometric assays for TSH. Clin. Chim. Acta 203, S5-S16.

8. Woodhead, J. S. \& Weeks, J. (1985) Circulating thyrotropin as an index of thyroid function. Ann. Clin. Biochem. 22, 455459.

9. Mendel, C. M., Frost, P. H. \& Cavalieri, R. R. (1986) Effect of free fatty acids on the concentration of free thyroxine in human serum: The role of albumin. J. Clin. Endocrinol. Metab. 63, 1394-1399.

10. Bonte, H. A., Vermes, I. \& Sluijs, V. (1989) Analytical and clinical evaluation of three sensitive TSH assays. Ann. Clin. Biochem. 26, 508-516.

11. Browning, M. C. K., Ford, R. P., Callaghan, S. J. \& Fraser, C. G. (1986) Intra and interindividual biological variation of five analytes used in assessing thyroid function: Implications for necessary standards of performance and interpretation of results. Clin. Chem. 32, 962-966.

12. Klee, G. G. \& Hay, I. D. (1987) Assessment of sensitive thyrotropin assays for an expanded role in thyroid function testing: Proposed criteria for analytic performance and clinical utility. J. Clin. Endocrinol. Metab. 64, 461-470.

13. Hershman, M., Pekary, E., Smith, V. P. \& Hershman, F. D. (1988) Evaluation of five high-sensitivity American thyrotropin assays. Mayo. Clin. Proc. 63, 1133-1139.

14. Nelson, J. C. \& Tomei, R. T. (1988) Direct determination of free thyroxin in undiluted serum by equilibrium dialysis/radioimmunoassay. Clin. Chem. 34, 1737-1744.

15. Aw, T. C. \& Wann, K. S. (1992) The use of an automated nonisotopic free thyroxine assay. Abstract. Clin. Chem. 38, 1093.
In summary, we found the Enzymun-Test ${ }^{\circledR}$ assays to be precise, of adequate sensitivity and robust. However, in a hospital setting, non-thyroidal illness and in vitro assay interference may compromise the clinical sensitivity and specificity of thyrotropin and free thyroxine measurement, such that measurement, of both analytes is required for initial evaluation of thyroid function. Automated immunoassay analysers, such as the ES300, make this approach economically more feasible.

16. Csako, G., Zweig, M. H., Glickman, J., Kestner, J. \& Ruddel M. (1989) Direct and indirect techniques for free thyroxin compared in patients with nonthyroidal illness. 1. Effect of free fatty acids. Clin. Chem. 35, 102-109.

17. Chopra, I. J., Chua Teco, G. H., Mead, J. F., Huang, T., Beredo, A. \& Solomon, D. H. (1985) Relationship between serum free fatty acids and thyroid hormone binding inhibitor in nonthyroid illnesses. J. Clin. Endocrinol. Metab. 60, 980-984.

18. Nicolsen, R. E., Reilly, C. P., Pannall, P. R., Esposito, L. \& Wellby, M. L. (1989) Do nonesterified fatty acids displace thyroxine from its plasma binding sites in severe nonthyroidal illness. Clin. Chem. 35, 931 -934 .

19. Liewendahl, K., Tikanoja, S., Mahonen, L. T., Helenius, T., Valimaki, M. \& Tallgren, L. G. (1987) Concentrations of iodothyronines in serum of patients with chronic renal failure and other nonthyroidal illnesses: Role of free fatty acids. Clin. Chem. 33, 1382-1386.

20. Tikanoja, S. H., Jontti, A. \& Liewendahl, B. K. (1989) Association between increased concentrations of free thyroxine and unsaturated free fatty acids in non-thyroidal illness: Role of albumin. Clin. Chim. Acta 179, 33-44.

21. Csako, G., Zweig, M. H., Benson, C. \& Ruddel, M. (1986) On the albumin dependence of measurements of free thyroxine 1: Technical performance of seven methods. Clin. Chem. 32, $108-115$.

22. Wellby, M. L. (1990) Clinical Chemistry of thyroid function testing. Adv. Clin. Chem. 28, 2-68.

23. Ford, C., Bartlett, W. A., Wells, F. E. \& Srivastava, U. (1993) A case of heterophilic antibody interference in the Amerlex$\mathrm{MAB} \mathrm{FT}_{4}$ assay. Abstract. Proc. of the Assoc. Clin. Biochem. Meeting. UK. July 1993, 43.

24. Lai, L. C., Day, J. \& Peaston, R. T. (1993) Spuriously high free thyroxine using the Amerlex $\mathrm{MAB} \mathrm{FT}_{4}$ assay. Abstract. Proc. of the Assoc. Clin. Biochem. Meeting. UK. July 1993, 44.

25. Bartlett, W. A., Browning, M. C. K. \& Jung, R. T. (1986) Artefactual increase in serum thyrotropin concentration caused by heterophilic antibodies with specificity for IgG of the family Bovidea. Clin. Chem. 32, 2214-2219.

26. Spencer, C., Eigen, A., Shen, D., Duda, M., Qualls, S., Weiss, S. \& Nicoloff, J. (1987) Specificity of sensitive assays of thy rotropin (TSH) used to screen for thyroid disease in hospitalised patients. Clin. Chem. 33, 1391-1396.

27. Wehmann, R. E., Gregerman, R. I., Burns, W. H., Saral, R. \& Santos, G. W. (1985). Suppression of thyrotropin in the low thyroxine state of severe nonthyroidal illness. N. Eng. J. Med. $312,546-552$.

28. Re, R. N., Kourides, I. A., Ridgway, E. C., Weintraub, B. D. \& Maloof, F. (1976) The effect of glucocorticoid administration on human pituitary secretion of thyrotropin and prolactin. J. Clin. Endocrinol. Metab. 43, 338-345.

29. Faber, J., Kirkegaard, C., Rasmussen, B., Westh, H., BuschSorensen, M. \& Jensen, I. W. (19.87) Pिituitary - thyroid axis in critical illness. J. Clin. Endoerinol. Metab. 65, 315-320. 
30. Stockigt, J. R., Lim, C. F., Barlow, J. W., Stevens, V., Topliss, D. J. \& Wynne, K. N. (1984) High concentrations of furosemide inhibit serum binding of thyroxine. J. Clin. Endocrinol. Metab. 59, 62-65.

31. Bayer, M. F., Macoviak, J. A. \& McDougall, R. I. (1987) Diagnostic performance of sensitive measurements of serum thyrotropin during severe nonthyroidal illness: Their role in the diagnosis of hyperthyroidism. Clin. Chem. 33, 2178-2184.

32. Spencer, C. A. (1988) Clinical utility and cost-effectiveness of sensitive thyrotropin assays in ambulatory and hospitalised patients. Mayo Clin. Proc. 63, 1214-1222.

33. Hollander, C. S., Scott, R. L., Burgess, J. A., Rabinowitz, D., Merimen, T. J. \& Openheimer, J. H. (1967) Free fatty acids: A possible regulator of free hormone levels in man. J. Clin. Endocrinol. Metab. 23, 1219-1223.

34. Eden, S., Jagenburg, R., Lindstedt, G., Lundberg, P. A. \& Mellstrom, D. (1984) Interrelationship among body mass, thyrotropin, thyroid hormones and thyroid hormone binding proteins in healthy 70 year old men. Clin. Chem. 30, 681-686.
35. Docter, R., Toor, H., Krenning, E. P., de Jong, M. \& Hennemann, G. (1993) Free thyroxine assessed with three assays in sera of patients with nonthyroidal illness and of subjects with abnormal concentrations of thyroxine binding proteins. Clin. Chem. 39, 1668-1674.

36. Becker, D. V., Bigos, S. T., Gaitan, E., Morris, J. C., Rallison, M. L., Spencer, C. A., Sugawara, M., Middlesworth, L. \& Wartofsky, L. (1993) Optimal use of blood tests for assessment of thyroid function. J. Am. Med. Assoc. 269, 2736-2737.

37. Spencer, C. A., Lo Presti, J. S., Middlesworth, L., Wartofsky, L., Becker, D. V., Bigos, S. T., Gaitan, E., Morris, J. C., Rallison, M. L. \& Sugawara, M. (1993) Screening for thyroid dysfunction: Which test is best? J. Am. Med. Assoc. 270, 22972298.

Dr I. Ramasamy

Department of Biochemistry

Repatriation General Hospital

Daws Road

Daw Park SA 5041

Australia 
